\title{
Lexical and Syntactical Competencies among English Major Students of the University of Bohol
}

\author{
LUZVIMINDA P. ABDUL \\ https://orcid.org/0000-0001-5655-6217 \\ Ipabdul@universityofbohol.edu.ph
}

\begin{abstract}
The purpose of this study was to assess the competency level of the English major students of the University of Bohol (UB), in the aspects of lexicon and syntax. The study further sought to find the correlation between lexical and syntactical competencies and the degree of variance on the different dimensions in lexicon and in syntax. The study made use of the descriptive method of research. It also made use of complete enumeration of the junior respondents from both the Teachers College and the College of Arts and Sciences for the second semester of school year 2016-2017. The results showed that the Junior English major students of UB had high competency level in lexicon. They performed high in context clues, word formation, and structural analysis but performed moderately in idioms. On the other hand, the students had a Moderate competency level in Syntax. They performed the best in subject-verb agreement but performed the worst in sentence modification/transformation. There was a correlation between lexical and syntactical competency; students who got high in lexicon were also high in syntax. There was also variance in the lexical competencies on the four dimensions. The English major students' competency in getting meaning through context clues, word formation and structural analysis and idioms were of varying extent. Students performed differently in all these aspects. Context clues got the highest, idioms got the lowest average competency. Subject-verb agreement obtained the highest average competency whereas sentence modification/transformation obtained the least.
\end{abstract}


Keywords: Lexicon, syntax, lexical competency, syntactical competency, English grammar, English vocabulary, English major students

\section{INTRODUCTION}

In the era of globalization, English has increasingly become the medium in every domain of communication, both in local and global contexts. As a result, the demand for speakers using English effectively is necessary for every country. English speakers are geographically dispersed throughout the world in large number, about 80 percent of which are non-native English speakers using English as a lingua franca - that is communication between speakers who have different first languages. English as a lingua franca entails innovations in both lexicon and syntax, particularly grammar (Jenkin, 2008). In the Philippines, the English language has become more popular as shown in a survey result that many activities are influenced by the English language and that it has become the preferred language than our official national language (Borlongan, 2009).

To have competence in the use of the English language is fundamental, hence, learning the correct use of the language placed a significant role. This paper makes this modest attempt to delve into the competency level of the English major students in terms of - syntax and lexicon which are both necessary for expressing one's ideas in using the English language.

The study is anchored on the theory of Krashen (1981) as cited by Schütz (2007) on second language acquisition (SLA) which stipulates that 'learning' requires conscious knowledge about the language, such as knowledge of grammar rules. It stresses that being sensible in grammar is an ability of an individual to demonstrate his awareness of the syntactical patterning of sentences in the language. Additionally, there are two independent systems of second language performance: 'the acquired system' and 'the learned system'. The 'acquired system' or 'acquisition' requires the learners to speak or to communicate. Learners may involve interaction to acquire the language. The 'learned system' or 'learning' requires conscious knowledge about the language, such as knowledge of grammar rules. In addition, In addition, the Monitor Theory makes some very specific hypotheses about the interrelation between acquisition and learning in the adult. Terrell (1986), further highlighted that in acquiring knowledge of the English language, the Natural approach might be used. The natural approach is based on the theory that language acquisition occurs only when students receive 
comprehensible input. He noted that fluency in the production of utterances is determined solely on the acquired knowledge while the learned knowledge enables the speaker to correct utterances before it is spoken with the use of mental processing, the monitor (Krashen \& Terrell 1983; Terrell, 1986).

Likewise, the Generative Syntactic theory which includes Transformational grammar, proposed by Noam Chomsky in 1957 tries to show the underlying structure of words in their deeper relationship to one another. Chomsky also believes that one must be knowledgeable in a language to be considered competent in it. Its immediate goal of linguistics is to develop formal, explicit models of various aspects of human language. It is through the development that formal claims about language can be tested. These formal levels are related to each other by special mappings, which transform one level into another (Chomsky, 2014).

The use of this model can be the basis for actual communication. Moreover, Bachman and Palmer (1982) proposed a much more comprehensive model of communicative competence. Bachman suggested a new model of communicative competence or, more precisely, the model of communicative language ability (CLA). This consists of organizational knowledge which includes grammatical knowledge of independent areas such as knowledge of vocabulary, morphology, syntax, phonology, and graphology; and pragmatic knowledge which also include lexical knowledge. Both knowledge in grammar and lexicon aid in the production of grammatically correct sentences as well as comprehension of their propositional content (Celce-Murcia, Dörnyei, \& Thurrell, 1995).

Bachman's theory of Communicative competence $(1988,1990)$ and Bachman and Palmer (1982), designs a framework of various components: One of which is Language Competence which includes sociolinguistic, strategic and grammatical competence: knowledge in lexicon, morphology, syntax, phonology/graphology and textual competence in controlling the formal structure of language for producing or recognizing grammatically correct sentences and for ordering these to form texts.

Several studies were conducted related to this investigation. Chang (2011), as he contrasted the use of grammar-translation method and communicative approach in English Language teaching, arrived at the conclusion that with the wrong use of grammar, words have no real meaning or sense. To be able to express one's self with competence in the use of the English language, knowledge of grammar should be applied. It 
is, therefore, a dire need for teachers to teach grammar not only for students to express themselves but also for them to fulfill their expectations in the learning of a language. There are no miracles on the way to learn a language. No matter how students are taught grammatical concepts, syntactic constructions and stylistic devices, or language conventions and editing concepts, they will not automatically make use of these in their talking.

Lauttamus, Nerbonne, \& Wiersma (2007) found out that 'juvenile' Finnish Australians are more contaminated or learned in the English language compared to the 'adults' as they were exposed earlier to the language. They also observed that adult English speakers demonstrate typical morpho-syntactic features of temporary shift and imperfect learning of English.

Luciana (2006) attempted to probe the degree to which the underlying process of output in a collaborative interactional grammar task can lead to grammar learning. She disclosed that such output could provide a rich forum for learning to take place through its mechanisms: gap-noticing, hypothesis testing, and metalinguistic function. A different impact upon different levels of students. The study also found out that a grammar sensitive task can pave the way to L2 grammar learning by pushing syntactic processing. Output serves a complementary function to foster L2 grammar learning.

The study of Chan (2004) shows evidence of syntactic transfer from Chinese to English based on data obtained from 710 Hong Kong Chinese ESL learners at different proficiency levels. The results showed that many of these learners in Hong Kong tended to think in Chinese first before they wrote in English, and that the surface structures of many of the interlanguage strings produced by the participants were very similar or even identical to the usual or normative sentence structures of Cantonese, the learners' first language.

Bowey (1996) observed that students who had varying decoding abilities were observed to differ in syntactic awareness. This was reflected in their ability to correct grammatically deviant sentences within an oral language task, even with general verbal ability effects covaried. Performance on the syntactic awareness task ("syntactic control") was correlated with measures of ongoing reading comprehension and comprehension monitoring and with performance on standardized tests of reading comprehension. 


\section{METHODOLOGY}

To acquire an accurate, factual and systematic data that can provide an actual picture of the data set reviewed, the descriptive method of research utilizing the questionnaire was used to determine the competencies in lexicon and syntax among the 32 respondents from the College of Arts and Sciences and Teachers College of the University of Bohol. It also used purposive universal sampling method for only the Junior English major students were the chosen respondents. However, all the officially enrolled Junior English majors were considered.

The standard tool designed by Dr. Jonathan Malicsi, formerly of the University of the Philippines and author of the English 1 and 2 manuals and workbooks that the English 1 and 2 teachers in this university are presently using was the primary source for the test questionnaire. The preparation of the test covered items taken from the Exit and Progress Tests in both English 1 and 2 subjects. However, there were some items in which the researcher utilized other sources: such as English Grammar books, Developmental Reading books, Vocabulary books and even from the Internet. The Language Test administered to the English major students was composed of two areas. The first pertains to Lexicon which included 25 items in each dimension. This totaled 100 items. Meanwhile, the second part was on Syntactic rules and patterns with 20 items per and a total of 100 points. The Language Test in two sets had a total of 200 items.

\section{RESULTS AND DISCUSSION}

\section{Profile of the Respondents}

The majority of the student respondents were between the ages of 18-20. Twenty-eight (87.50\%) of them were taking up Bachelor of Secondary Education - Major in English. Meanwhile, Bachelor of Arts Major in English only had four (12.50\%) respondents.

\section{Level of Students Lexical Competency}

Lexical competence has been suggested to be a cluster of knowledge (form, meaning and use of a lexical item), skills and abilities that a person develops and deploys in different contexts of communication (Caro, 2017). 
Table 1. Level of students' lexical competence

$\mathrm{N}=32$

\begin{tabular}{|l|l|l|l|}
\hline Items & Average Competence & Level of Lexical Competence & Rank \\
\hline 1. Context clues & 73.13 & High Competency & 1 \\
\hline 2. Word Formation & 69.63 & High competency & 2 \\
\hline 3. Structural Analysis & 60.63 & High competency & 3 \\
\hline 4. Idioms & 53.88 & Moderate Competency & 4 \\
\hline Average & 64.31 & High Competency & \\
\hline
\end{tabular}

Rating:

$\begin{array}{lll}0 & 19 & \text { No Competency } \\ 20 & 39 & \text { Slight Competency } \\ 40 & 59 & \text { Moderate Competency } \\ 60 & 79 & \text { High Competency } \\ 80 & 100 & \text { Very High Competency }\end{array}$

The overall rating of students' level of competency in lexicon showed that the English major students had High Competency level in lexical aspect for obtaining an average of 64.31. This result signified a continued need for the students to be lexically enhanced to meet the maximum competency level as what Bachman theorized in the study of Celce-Murcia et al., (1995) that knowledge in lexicon contributes to one's ability in using the English language for communicative purposes.

\section{Level of Students' Syntactic Competence}

Competence in syntax included students' ability to apply the correct use of the following: Subject-Verb agreement, verb tenses, sentence modification/ transformation, recognizing sentence parts/ functions and sentence embedding.

Table 2. Level of Students' Syntactic Competence

$\mathrm{N}=32$

\begin{tabular}{|l|l|l|l|}
\hline Items & $\begin{array}{l}\text { Average } \\
\text { Competence }\end{array}$ & Level of Syntactical Competence & Rank \\
\hline 1. Subject-verb agreement & 73.44 & High Competency & 1 \\
\hline 2. Verb tenses & 54.38 & Moderate Competency & 3 \\
\hline $\begin{array}{l}\text { 3. Sentence modification/ } \\
\text { transformation }\end{array}$ & 23.13 & Slight Competency & 5 \\
\hline
\end{tabular}




\begin{tabular}{|l|l|l|l|}
\hline $\begin{array}{l}\text { 4. Recognizing sentence } \\
\text { parts/functions }\end{array}$ & 55.94 & Moderate Competency & 2 \\
\hline 5. Sentence embedding & 42.50 & Moderate Competency & 4 \\
\hline Average & $\mathbf{4 9 . 8 8}$ & Moderate Competency & \\
\hline
\end{tabular}

$\begin{array}{lll}\text { Rating: } & & \\ 0 & 19 & \text { No Competency } \\ 20 & 39 & \text { Slight Competency } \\ 40 & 59 & \text { Moderate Competency } \\ 60 & 79 & \text { High Competency } \\ 80 & 100 & \text { Very High Competency }\end{array}$

Table 2, depicted the summary of the competency of the English major students in Syntax. As reflected, the average yielded 49.88, described as Moderate Competency. This illustrates the need of the English majors to augment their syntactical knowledge as what Krashen, as cited by (Schütz, 2007); Chomsky (2014) and Bachman \& Palmer (1982) posited that one must be knowledgeable of the structure of the language to demonstrate awareness of syntactical patterns of sentences and to recognize grammatically correct sentences to be considered competent in the use of the English language.

Statistical analysis between lexical and syntactical competence showed a significant correlation, students who obtained high scores in lexicon also attained high scores in syntax, while those who obtained a low score in the lexicon, also obtained a low score in syntax. There was also a significant variance in the different lexical, and syntactical dimensions understudied.

\section{CONCLUSION}

The students had high competency level on context clues, word formation, and structural analysis; however, they had moderate competency level in idioms. In totality, the English major students were highly competent in lexicon.

The students performed the most in subject-verb agreement but performed the least in sentence modification/ transformation. As a whole, student respondents had moderate competency level in syntax. 


\section{REFERENCES CITED}

Bachman, L. F., \& Palmer, A. S. (1982). The construct validation of some components of communicative proficiency. TESOL quarterly, 16(4), 449-465. Retrieved from https://goo.gl/wLuSMz (accessed last 16 January 2017).

Borlongan, A,M, (2009) A Survey on Language Use, Attitudes and Identity in Relation to Philippine English among Young Generation Filipinos: An Initial Sample from a Private University. Online Submission, 3,74107. Retrieved from https://goo.gl/7F5Erz, (accessed last 16 February 2017).

Bowey, J. A. (1986). Syntactic awareness in relation to reading skill and ongoing reading comprehension monitoring. Journal of Experimental Child Psychology, 41(2), 282-299.Retrieved from https://goo.gl/Gy4fck, (accessed last 16 January 2017).

Caro, K. (2017). Lexis, lexical competence and lexical knowledge: a review. Journal of Language Teaching and Research, 8(2), 205. Retrieved from https://goo.gl/LXkWug, (accessed last 31 March 2017).

Celce-Murcia, M., Dörnyei, Z., \& Thurrell, S. (1995). Communicative competence: A pedagogically motivated model with content specifications. Issues in Applied linguistics, 6(2), 5-35. Retrieved from https://goo.gl/oVSAhp, (accessed last 16 January 2017).

Chang, S. C. (2011). A contrastive study of grammar translation method and communicative approach in teaching English grammar. English Language Teaching, 4(2), 13. Retrieved from https://goo.gl/vmdRMb, (accessed last 16 January 2017).

Chan, A. Y. (2004). Syntactic transfer: Evidence from the interlanguage of Hong Kong Chinese ESL learners. Modern language journal, 56-74. Retrieved from https://goo.gl/hIWypq, (accessed last 16 January 2017).

Chomsky, N. (2014). Aspects of the Theory of Syntax (Vol. 11). MIT press. Retrieved from https://goo.gl/pbCvBe, (accessed last 16 January 2017). 
Jenkins, J., \& Leung, C. (2014). English as a lingua franca. John Wiley \& Sons, Inc. Retrieved from https://goo.gl/zGBZPy, (accessed last 13 January 2017).

Krashen, S. D., \& Terrell, T. D. (1983). The natural approach: Language acquisition in the classroom. Retrieved from https://goo.gl/23XaBZ, (accessed last 13 January 2017).

Lauttamus, T., Nerbonne, J., \& Wiersma, W. (2007). Detecting syntactic contamination in emigrants: the English of Finnish Australians. SKY Journal of Linguistics, 20, 273-307. Retrieved from https://goo.gl/ zfrDL6, (accessed last 12 January 2017).

Luciana. (2006). Roles of Output in Foreign Language Learning: A Case of Collaborative Grammar Task. The Journal of Asia TEFL, 3(3), 143-176. Retrieved from https://goo.gl/mJqyr2, (accessed last 12 January 2017).

Schütz, R. (2007). Stephen Krashen's theory of second language acquisition. English made in Brazil, 2(2), 2007. Retrieved from https:// goo.gl/BvD6nf, (accessed last 16 January 2017).

Terrell, T. D. (1986). Acquisition in the natural approach: The binding/access framework. The Modern Language Journal, 70(3), 213-227. Retrieved from https://goo.gl/uHN56W, (accessed last 15 January 2017). 